\title{
SUPPORTING RENEWABLE ENERGY DEVELOPMENT THROUGH INTERNATIONAL SYNERGIES: OBSTACLES AND OPPORTUNITIES IN THE CHINESE CONTEXT
}

\author{
DR STEVEN GEROE \\ Lecturer in Law, La Trobe University, Australia.
}

\begin{abstract}
This paper examines opportunities and obstacles to Chinese and international renewable energy development through international synergies. Firstly, international involvement in the consultative drafting process of Chinese renewable energy regulation is considered, based on interviews in Chinese institutions involved in this process. This evidence establishes that widespread institutional synergies have been established between Chinese and international renewable energy institutions, forming the basis for cooperation in regulatory development, technological research and development and joint renewable energy projects. The research interviews are then situated in the context of recent scholarly research on international investment synergies in China, focusing on licensing agreements, joint development, and mergers and acquisitions, in 'learning hubs' of concentrated renewable energy research and development and large-scale commercialisation. Obstacles are considered primarily in terms of non-tariff barriers and government procurement policies and practice. These measures have been a significant factor in China achieving its stated objective of substantial self-reliance in renewable energy production. While there is widespread and continuing evidence of international institutional and investment synergies, this has not impeded the Chinese government's planned dominance of the domestic market by Chinese firms. Nonetheless, innovative technology is needed to advance China's strategy of lowcarbon economic modernisation, such as smart grids, offshore wind and advanced thin film materials. While these may currently be specialised or niche areas, the scale of Chinese low-carbon development presents substantial investment opportunities. The evidence presented in this paper of synergies between Chinese and international renewable energy institutions, and of investment synergies in international learning hubs in China, indicates that there is a functional basis for foreign invested enterprises to participate in these opportunities.

Keywords: barrier, Chinese, institutions, investment, opportunity, regulatory development, renewable energy, synergy, trade.
\end{abstract}

\section{INTRODUCTION}

This paper examines the problem of how to maximise the mutual benefits of cooperation between Chinese and foreign/international renewable energy institutions and enterprises. Accordingly, international involvement in the consultative drafting process of Chinese renewable energy regulation is considered, based on interviews in Chinese institutions involved in this process. This evidence establishes that widespread institutional synergies have been established between Chinese and international renewable energy institutions, forming the basis for cooperation in regulatory development, technological research and development and joint renewable energy projects. The research interviews are then situated in the context of recent scholarly research on international investment synergies in China, focusing on licensing agreements, joint development, and mergers and acquisitions, in 'learning hubs' of concentrated renewable energy research and development and large-scale commercialisation. Obstacles are then considered, primarily in terms of non-tariff barriers and government procurement policies and practice, which have supported China's achievement of its stated objective of substantial self-reliance in renewable energy production. Nonetheless, innovative technology is needed to advance China's strategy of low-carbon economic modernisation, 
such as smart grids, offshore wind and advanced thin film materials. While these may currently be specialised or niche areas, the scale of Chinese low-carbon development presents substantial investment opportunities. The evidence presented in this paper of synergies between Chinese and international renewable energy institutions, and of investment synergies in international learning hubs in China, indicates that there is a functional basis for foreign invested enterprises to participate in these opportunities.

China's overall policy framework for renewable energy development is grounded in its complementary economic modernisation and climate change objectives, which forms the basis for state support of renewable energy development through both state-related and private sector institutions. The relationship between climate change mitigation and economic modernisation is clearly set out in the National Development and Reform Commission (NDRC) Climate Change Whitepaper (2011): 'China will foster the concept of green and low-carbon development, and take addressing climate change as an important strategy for its economic and social development as well as an important opportunity for economic restructuring and the transformation of its economic development pattern' State Council [1]. An important influence has been Hu Angang's account of the success of nations that have benefitted from 'waves of industrialisation and modernisation [that] have been tied to the emergence of important new energy technologies' [2]. Similarly, both Zhou Dadi, former Director of the NDRC's Energy Research Institute and Chinese Premier Li Keqiang have argued that China must remain competitive with developed nations that are decarbonising their economies [3]. This relationship between renewable energy and China's economic objectives is reflected by its inclusion as an emerging, strategic industry in the 12th Five-Year Plan National People's Congress [4]. Thus, renewable energy development is a core element of China's strategy for economic development through low-carbon, high technology innovation. This policy position has formed the basis for the development of specialist renewable energy institutions and their collaborative projects with international institutions, as well as private sector investment synergies.

\section{PROBLEM STATEMENT AND OBJECTIVES}

This paper examines the problem of how to maximise the mutual benefits of cooperation between Chinese and foreign/international renewable energy institutions and enterprises. The objective is to identify obstacles to such international cooperation, and opportunities to enhance it through international institutional collaboration and private sector research and development (R\&D) and investment synergies. While renewable energy R\&D and investment clearly involves technological and financial aspects, the focus of this paper is on regulatory and policy aspects.

Accordingly, the basis for international cooperation in international institutional collaboration and private sector research and development (R\&D) and investment synergies is considered. Obstacles to international cooperation created by non-tariff barriers, government procurement measures and policy of Chinese renewable energy self-sufficiency are then examined. Findings and conclusions are based on this analysis.

\section{INTERNATIONAL INSTITUTIONAL SYNERGIES}

International institutional cooperation has formed an important basis for governmental and private sector linkages in the Chinese renewable energy field. As such, it forms an important basis for the international investment synergies discussed in the following section. International input into the Chinese renewable energy consultative drafting process began in earnest with the drafting of the Chinese Renewable Energy Law in the early 2000s [5]. At this time, 
the National Development and Reform Council (NDRC) Drafting Group for the Renewable Energy Law organized symposiums, which were the only way international organizations and individuals could directly input into the consultative drafting process. Organizations involved in these symposiums given included the World Bank, the Asian Development Bank, the United Nations Development Program and the US Energy Foundation. Within the NDRC drafting group, sub-groups investigated renewable energy laws of different countries. Overall, the USA and Germany were the most influential countries in the drafting process [6]. A separate 'Academic Drafting Group' based at Tsinghua University also undertook extensive comparative research on developed, developing and transition countries' renewable energy-related laws [7].

This section does not provide an overall account of major international collaborative projects such as the World Bank funded China Renewable Energy Scale-up project (CRESP), which have been the subject of several other studies. Rather it provides interview evidence of the ways in which Chinese renewable energy institutions collaborate with international organisations the regulatory research and drafting process. As such it provides detailed information as to the ways in which international institutional cooperation has been implemented in Chinese renewable energy development. This process of cooperative regulatory development forms a significant element of the basis for the investment synergies discussed in the following section. Firstly, the East Asia Secretariat of the intergovernmental and private sector Renewable Energy and Energy Efficiency Partnership (REEEP) is hosted by the Chinese Renewable Energy Industry Association (CREIA). CREIA's international role includes the involvement of international renewable energy firms in its workshops, conferences and exhibitions. CREIA has also worked with the United Nations Development and Environment Programs, the World Bank, the US Energy Foundation, the Sino-Danish Renewable Energy Development Project, and the European Union. CREIA applies to these organizations for research funding, but remains independent in conducting research relating to Chinese renewable energy development [8]. Megan Tang cited the US Energy Foundation, however, as an example of direct international participation in CREIA research through provision of specialist expertise. These internationally supported projects have had both a research and a project implementation focus. She indicated that REEEP is only involved in regulatory development in China through its support of CREIA research projects REEEP [9].

The China National Renewable Energy Centre (CNREC) was established under the Sino-Danish Renewable Energy Development Program in 2012. It provides comprehensive regulatory research for the National Energy Agency and the State Council, as well as research and technical expertise for renewable energy-related standards and overall industry development. CNREC plays a complementary role to the Ministry of Science and Technology (MOST) with respect to demonstration projects, by providing specialist renewable energyrelated expertise CNREC [10]. Aspects of CNREC's cooperative relationship with its Danish partner include a China Renewable Energy Analysis Model (based on a Danish model), and a Renewable Energy Information and Analysis Database of national and international data on renewable energy development, in cooperation with the International Energy Agency and other international experts, and support from the Danish Energy Agency regarding methodology [11]. CNREC's administrative structure includes a Danish Chief Expert and several international members of the Advisory Committee Sandholt CNREC [12].

Shi Jingli's responses regarding the relationships between Chinese renewable energy institutions and international institutions were consistent with those of Megan Tang. In terms of project selection, she said that the CNREC applies to many organizations for support including The US Energy Foundation, the China Renewable Energy Scale-up Project (CRESP) and 
the Asian Development Bank. CNREC generally is generally free to come up with its own projects and business plans, but will 'discuss projects with different organizations.' She also referred to the direct involvement of the Energy Foundation/Centre for Resource Solutions (CRS) in CNREC renewable energy projects, through provision of specialist expertise. In more cultural or attitudinal terms, she observed that at CNREC 'we often say there are no boundaries for research' [13].

Neither Chinese nor foreign invested private enterprises directly (at least openly) participate in the consultative drafting process. They do provide information relevant to regulatory measures, for example details of prices and materials relevant to an investigation into alleged dumping of poly silicon into China [14]. Private firms also participate in conferences specifically designed to gather feedback on regulatory measures organised by Chinese renewable energy institutions such as CREIA, and CNREC [13]. Membership in Chinese industry organisations of both Chinese and foreign invested enterprises can be an effective means of indirectly influencing government. For example, the Tianjin Wind Energy Association (TWEA) organised a conference aiming to delay implementation of a barriers to entry regulation on wind turbine manufacturers in 2011. Due to the importance of the wind turbine manufacturing industry in Tianjin, the TWEA's proposed conference was supported with alacrity by the Tianjin local government and the Tianjin Development and Reform Commission. The conference was attended by representatives of the central government Ministry of Information and Industry, and was successful in delaying the measure [15].

The interviews and other evidence established that international participation has been a significant feature of Chinese renewable energy regulatory development from at least the early 2000s. Its salient aspects include participation in conferences organised by Chinese renewable energy institutions, hosting visiting Chinese delegations, participating in jointly conducted research, funding research conducted by Chinese institutions, provision of data and expertise through international organisations such as the International Energy Agency and the World Bank, and joint establishment of major national renewable energy institutions such as the Sino-Danish China National Renewable Energy Centre. These processes of cooperative regulatory development have formed an important basis for the emergence of the private sector research and development and investment synergies discussed in the following section.

\section{INTERNATIONAL INVESTMENT SYNERGIES}

A significant feature of Chinese and indeed global renewable energy development is the increasing trend towards internationalisation of R\&D and investment. Together with the institutional synergies discussed in the previous section, this significantly contributes to the basis for involvement of foreign invested enterprises in China's large-scale renewable energy development. This trend is largely occurring through the increasing diversity of means of technology transfer - primarily licensing agreements, joint development, and mergers and acquisitions [16]. These developments, and the resultant globalised 'learning hubs' or networks evolving in major centres of renewable energy development such as China, are creating a substantially private sector driven actuality of technology innovation less characterised by national borders [17]. Indeed China's PV manufacturing industry was created extraordinarily rapidly, largely on the basis of licensed and imported equipment and outright purchase of foreign firms in order to acquire technology [17],[16]. Nonetheless increasing joint research and development of technologies, as opposed to simply acquiring foreign technology, reflects China's ambition to move up the value chain towards an innovation driven economy. 
More broadly, this is representative of the sharply increasing globalisation of clean energy technology, with China dominating the rising trend of investment by developing economies in developed country markets [18]. Such international commercial synergies may provide an optimal approach for Chinese industry development, in terms of utilising leading technology (both Chinese and international) to address technical implementation issues such as technical standards and grid integration of high proportions of renewable energy.

In turn, this cooperative approach could be a factor in easing trade tensions regarding market access in China, for example in large-scale wind projects. To some degree this would mark a change in direction from the existing Chinese policy of 'domestic manufacturing capacity based mainly on China's own IPR's satisfying the need for deploying renewable energy on a large scale in China' NDRC [19]. While renewable energy is a category of encouraged foreign investment in China Ministry of Commerce [20], overall trends in recent years have been more towards ownership of generation assets by Chinese utilities and other state-owned entities, and financial support of domestic manufacturing entities [21], and outbound Chinese investment in the sector. While data regarding such commercial transactions is not consistently available, several public and private sector reports have endeavoured to quantify these trends. For example, between 2003 and 2013, 54 (out of 124) outbound Chinese direct foreign renewable energy investments for which financial data was available invested almost US $\$ 40$ billion in total [18]. One factor driving this trend is the need to grow export markets for Chinese manufactured renewable energy products, particularly in the context of declining subsidy support from some developed country governments. In turn, this provides a rationale for large-scale financial support of Chinese companies making such investments through state-related banks [18]. China is now the fifth-largest investor in other emerging markets, with \$US 19.7 billion since 2005 [22]. In the context of overall Chinese investment into the EU exceeding that of the EU members into China, Chinese entities have made renewable energy investments in most EU countries. In contrast, the highest levels of renewable energy investment into emerging-markets in the past decade have been Chile (91 projects totalling \$28.7bn; Romania (91 projects, $\$ 25.4 \mathrm{bn}$ ); and Brazil (76 projects, $\$ 20.5 \mathrm{bn})$. China is eighth (78 projects, $12.3 \mathrm{bn}$ ) [23]. These broader investment trends form the context for the evaluation in the following section of limiting factors on the participation of foreign invested enterprises in the Chinese renewable energy sector.

\section{OBSTACLES TO INTERNATIONAL INVESTMENT SYNERGIES}

This section considers non-tariff barriers and government procurement policies that have constrained the participation of foreign invested entities in the Chinese renewable energy industry. NDRC Medium to Long-Term Plan for Renewable Energy (2007) Paragraph 5.5 stated China's strategy of substantial self-reliance in the renewable energy sector:

By 2010, a basic system of renewable energy technologies and industry will have been established, so that equipment capability based mainly on domestic manufacture will have been established. By 2020, a relatively complete renewable energy technology and system will have been established, so that domestic manufacturing capacity based mainly on China's own IPR's will have been established, satisfying the need for deploying renewable energy on a large scale in China. NDRC [19]

As Johanna Lewis argues: 'China always intended for its wind industry to ultimately consist of Chinese-owned firms and Chinese-owned technology, and it established a national innovation system that left little to chance in ensuring that this goal was met' [16]. More specifically, imported wind turbines were exempt from customs duties from 1990 to 1995 to 
promote wind development. As the Chinese wind turbine industry developed, higher duties were imposed on imported complete turbines and a lower duty on imported components, in order to encourage local turbine manufacture with some use of international components that China was unable to produce [24]. Similarly, as an International Renewable Energy Agency (IRENA) and Global Wind Energy Council (GWEC) report observes, 70\% local content provisions for wind turbines were abolished in 2010 after 'the domestic industry had been fully established with companies covering the whole supply chain and international players coming to set up their manufacturing facilities in China' [25]. Similarly, a 2012 plan for solar energy specified that $80 \%$ of production equipment and associated materials for photovoltaic cells was to be produced domestically by 2015 [26].

According to the IRENA/ GWEC report, the wind concession program promoted domestic projects through competitive bidding. For example, in 2009 seven domestic projects were selected to supply over $5 \mathrm{GW}$ of wind to 25 projects in three sites in Inner Mongolia and Hebei provinces. This program has been dominant in Chinese wind development, with seven $10 \mathrm{GW}$-size development areas being selected in six provinces since 2009. Large-scale concession tenders also played a significant role in promoting the development of the wind power sector during its earlier stages [25]. By 2013, the 'Big Five' Chinese power producers and a small number of major state-owned enterprises held over $80 \%$ of the total wind power market. The remaining $20 \%$ is increasingly owned by Chinese utilities owned by provincial governments. 'Private enterprise and foreign-owned developing businesses represent a limited share of the total wind capacity of the country' [25]. While the contentious issues of subsidies is beyond the scope of this paper, international disputes have included loans at preferential interest rates as well as direct subsidies. For example, Joel Eisen indicates that 'the state-owned China Development Bank made \$42 billion in loans in 2010 to solar and wind energy companies, a sum that well exceeds comparable financing levels in the United States' [27].

Government procurement (GP), while not the subject of litigation in the WTO dispute resolution system, has nonetheless been the subject of some international tension. The value of Chinese GP is around 20\% of the GDP, roughly the size of the South Korean economy EU Chamber of Commerce [28]. As China is not a signatory party to the WTO Plurilateral Agreement on Government Procurement (the GPA), this issue has been approached on a diplomatic level and through such commercial organizations as the EU Chamber of Commerce. Chinese GP has been prominently debated in relation to contracts for large-scale wind farm development. According to an EU Chamber of Commerce Report, the primary concerns of EU business leaders operating in China surveyed 'related to obtaining accurate information as to tenders including detailed bid evaluation criteria, the decentralization of tenders leading to increased costs and reduced transparency, unfair implementation of GP awards and unsatisfactory appeals procedures' EU Chamber of Commerce [28]. As Wang Ping argues: '. . . It is evident that in recent years China has intensified the use of government procurement as a policy instrument to promote national industrial and environmental policies' [29]. More specifically, GP has been used to promote renewable energy-related products. This was implemented through NDRC Circular 618 2009, which 'identified six broad categories of products that were to be targeted, one of which was "new energy and equipment", [26]. Sub-categories included wind, solar, and biomass technologies. It is important to note, however, that allegations of protectionism in the renewable energy sector do not only relate to China. For example, Melendez-Ortiz et al. argue that national procurement regimes in general show 'evidence of opacity, lack of accountability and discrimination' [30]. Thus, Chinese government procurement processes lacking in transparency regarding bid criteria and 
decision-making processes must be viewed in this international context. Nonetheless Chinese non-tariff barriers and government procurement policies must be considered as constraining factors on the participation of foreign invested enterprises in China's large-scale renewable energy development, and thus on the impact of the institutional and investment synergies the subject of this paper.

\section{PROSPECTS FOR INTERNATIONAL SYNERGIES}

Reforms to international trade-related measures such as government procurement, non-tariff barriers and subsidies may have little more than incremental advantages for foreign invested enterprises in China. This is primarily because large-scale Chinese firms already dominate the wind, solar and hydro domestic market. Despite China's substantial renewable energy industrial self-sufficiency, market opportunities for foreign enterprises in China continue to exist for the same reasons they have in the past - to provide advanced technology and skills needed for Chinese economic development and modernisation. Opportunities are likely to present in areas requiring technology upgrading and innovation, as opposed to areas of relatively mature technology such as onshore wind turbine manufacture and wind farms. Recent examples from private sector analysis and media reports include foreign involvement in offshore wind projects, smart grid technology [31] and advanced thin film photovoltaic materials [32]. While these are currently specialised niche or prospective technologies, this is not to say that scale of the potential market is small. China's increasingly credible intellectual property rights regime provides some assurance in the context of joint development [17]. Nonetheless technology transfer or sharing is likely to be a central element of joint venture or licensing agreements, perhaps providing more certainty in terms of financial outcomes of rolling out technology in China. While assessment of prospects of foreign invested firms is well beyond the scope of this paper, total foreign direct investment in China remains at very high and increasing levels Chinese Ministry of Commerce [33]. This indicates a significant degree of acceptance of foreign ownership and profit repatriation by foreign invested enterprises in China. Despite continuing substantial Chinese ownership in the energy sector post market reforms [34], present trends indicate that foreign investment/equity interest will continue to be encouraged by the Chinese government and viable in specific areas requiring technology innovation and upgrading. It is probable that China, and indeed the world, is in the early stages of the transition to a low-carbon economy. Given the scale of the Chinese economy, and the clear policy and financial commitment the Chinese central government has made to low-carbon development, opportunities for foreign invested firms in the renewable energy field are likely to remain significant.

\section{FINDINGS}

\subsection{International institutional cooperation}

International participation has been a significant feature of Chinese renewable energy regulatory development from at least the early 2000s. It includes participation in conferences organised by Chinese renewable energy institutions, jointly conducted research, funding research conducted by Chinese institutions, provision of data and expertise, and establishment of institutions such as the Sino-Danish China National Renewable Energy Centre. Cooperative regulatory development, implemented through these means, has formed an important basis for private sector research and development and investment synergies. 


\subsection{International investment synergies}

A significant feature of Chinese and global renewable energy development is an increasing trend towards internationalisation of $\mathrm{R} \& \mathrm{D}$ and investment. This trend is largely occurring in China through licensing agreements, joint development, and mergers and acquisitions. While renewable energy is a category of encouraged foreign investment in China, overall trends in recent years have been more towards ownership of generation assets by Chinese utilities and state-owned entities, financial support of domestic manufacturing entities, and outbound Chinese investment in the sector.

\subsection{Obstacles to international investment synergies}

China has pursued a policy of renewable energy self-sufficiency, as stated in planning documents of the National Development and Reform Commission. This policy has been an element of the rationale for non-tariff barriers favouring import substitution by Chinese manufactured renewable energy-related products. Chinese government procurement and related measures have also formed a significant element of state-based economic support of Chinese domestic renewable energy production.

\subsection{Future opportunities for research and investment cooperation}

Opportunities are more likely to present in areas requiring technology upgrading and innovation, as opposed to areas involving relatively mature technology. Technology transfer or sharing is likely to be a significant element of joint venture or licensing agreements, and has the potential to provide a degree of certainty with respect to risks of rolling out technology in China. Presently niche areas of emerging high technology may represent significant market opportunity, given the scale of Chinese renewable energy development. Investment synergies based on existing trends have the potential to ameliorate both international trade tensions, and technical implementation issues in Chinese renewable energy development. International institutional cooperation has been and can continue to be a key element of private sector synergies in the Chinese renewable energy sector.

\section{CONCLUSIONS}

International institutional synergies contribute to the Chinese regulatory process through regulatory research and consultative drafting. This collaborative approach facilitates private sector investment synergies, increasingly implemented through licensing, joint venture agreements and M\&A in international 'learning hubs' in China. Hence, despite China's policy of substantial self-reliance in the renewable energy sector, non-tariff barriers directed toward import substitution, government procurement policies and related investment trends, there is a functional basis for foreign investment. Opportunities for international investment are most likely to present in areas of advanced technology. Given the scale of Chinese renewable energy development, current niche areas of high technology may represent significant market opportunity. This has the potential to ameliorate international trade tensions, and to address technical implementation issues through application of leading edge technology in China. The interview evidence of productive international institutional cooperation in Chinese regulatory development provides a considerable basis for optimism that this can be achieved. 


\section{REFERENCES}

[1] Information Office of the State Council PRC, China's Policies and Actions for Addressing Climate Change, Part VII, Objectives, Policies and Actions during the 12th Five-Year Plan Period, Part VII Section 2, 'Policies and Actions', 9, pp. 131-135, 2011. http://news.xinhuanet.com/english2010/china/2011-11/22/c_131262368.htm

[2] Olivia T Boyd., 'China's energy reform and climate policy: the ideas motivating reform', Working Paper 1205, Centre for Climate Economics and Policy Australian National University, pp. 12, May 2012. http://www.academia.edu/1620811/ Chinas_Energy_Reform_and_Climate_Policy_The_Ideas_Motivating_Change

[3] Zhang, S., Andrews-Speed, P., Zhao, X. \& He, Y., 'Interactions between renewable energy policy and renewable energy industrial policy: a critical analysis of china's policy approach to renewable energies', Energy Policy, 62, pp. 342-353, 350, 2013. https://doi.org/10.1016/j.enpol.2013.07.063

[4] National People's Congress. China's Twelfth Five-Year Plan, Chapter ten: 'foster and develop strategic emerging sectors', Section 2, Column 5, 2011-2015. http://www.britishchamber.cn/content/chinas-twelfth-five-year-plan-2011-2015-fullenglish-version

[5] Hamrin, J., China's new renewable energy law: the California connection. Golden Gate University Law Review, 36(3), pp. 86, 413, 2006.

[6] Interview with Professor Li Yanfang, Renmin University, Li Yanfang is the Director of the Environmental and Resources Law Teaching and Research Center at Renmin University Law School: Beijing, 10 November, 2012.

[7] Interview with Associate Professor Deng Haifeng, Tsinghua University, Beijing, 9 November, 2012.

[8] Interview with Megan Tang, CREIA Offices. Megan Tang is General Secretary of the Chinese Renewable Energy Association: Beijing, 18 December, 2012.

[9] For REEEP East Asia projects see Project Portfolio: East Asia. http://www.reeep.org/ projects

[10] China National Renewable Energy Centre web site About us - overview. http://www.cnrec.org.cn/english/aboutcnrec/overview/

[11] Kaare Sandholt (Chief Expert at CNREC) 'Sino-Danish Cooperation', power point for ThinkChina.dk event: Beijing, 17 December, 2012. http://www.thinkchina.ku.dk/ boxes/powerpointsgg/Microsoft_PowerPoint_-_Kaare_Sandholt.pdf

[12] CNREC web site http://www.cnrec.org.cn/english/aboutcnrec/organization

[13] Interview with Shi Jingli CNREC. Shi Jingli is Director of the Policy Research department of CNREC: Beijing, 4 January, 2013.

[14] Interview with Mr Fei Zhong, conducted by teleconference between the offices of Chen \& Co Lawyers, Shanghai and GCL Poly Holdings, Suzhou, 24 January, 2013.

[15] Interview with Wang Changgui, offices of Tianjin Wind Energy Association, Wang Changgui is Director of the TWEA: Tianjin, 11 January, 2013.

[16] Lewis, J.L., Green Innovation in China: China's Wind Power Industry and the Global Transition to a Low-carbon Economy, Columbia University Press, p. 35, 2013.

[17] Kelly, G., The Globalization of Clean Energy Technology: Lessons from China, MIT Press, pp. 19-20, 156-157, 174, 176, 2014.

[18] Xiaomei, T., Clifford, P., Yingzhen, Z. \& Jianwen, B., 'China's Overseas Investments in the Wind and Solar Industries: Trends and Drivers', Working Paper for the World 
Resources Institute, Washington DC, p. 1, 2013. http://www.wri.org/sites/default/files/ pdf/chinas_overseas_investments_in_wind_and_solar_trends_and_drivers.pdf

[19] NDRC Medium and Long-Term Development Plan for Renewable Energy, paragraph 5.5, September 2007.

[20] PRC Ministry of Commerce, Catalog for the Guidance of Foreign Investment Industries (amended in 2011, effective February 2012), [IV.1]. http://english.mofcom.gov.cn/ article/policyrelease/aaa/201203/20120308027837.shtml

[21] Dodson, B., China Fast Forward: The Technologies, Green Industries and Innovations Driving the Nation's Future, John Wiley \& Sons, p. 89, 2012.

[22] Courtney, F., Emerging market renewables: where's the FDI? Financial Times, online, Data sources from FDI Markets, 8 December, 2015. http://www.ft.com/cms/ s/3/3c96c24a-9daa-11e5-8ce1-f6219b685d74.html\#axzz4D1M7QKB2

[23] Ping, L. \& Francesca, S., 'The Integration of Chinese and European Renewable Energy Markets: The Role of Chinese Foreign Direct Investments', Energy Policy 81 (2015): p. 14, Table 2 'Country Distribution of Chinese Outward FDI in RE Sectors (2004-2013).

[24] Lewis, J.I., A Review of Potential International Trade Implications of Key Wind Power Industry Policies in China, report for United States Energy Foundation China Sustainable Energy Program, p. 3, October 2006. http://www.resource-solutions.org/ pub_pdfs/China.wind.policy.and.intl.trade.law.Oct.07.pdf

[25] Shruti, S. \& Steve, S. (lead authors)., 'Thirty years of policies for wind energy: lessons from twelve wind energy markets: the history and evolution of china's wind energy sector market', International Renewable Energy Agency and Global Wind Energy Council Report, 'The History and Evolution of China's Wind Energy Sector Market', 29, 2012. http://www.irena.org/DocumentDownloads/Publications/IRENA_GWEC_ WindReport_China.pdf

[26] Kennedy, A.B., China's search for renewable energy: pragmatic techno-nationalism. Asian Survey, 53(5), pp. 909-930, 925, n. 54, 2013. https://doi.org/10.1525/ as.2013.53.5.909

[27] Eisen, J.B., The new energy geopolitics?: china renewable energy and the "greentech race" Chicago-Kent Law Review, 86, pp. 9, 29, 2011.

[28] European Chamber of Commerce 'Public Procurement in China: European Business Experiences Competing for Public Contracts in China' (Report November 2011), pp. 21-23.

[29] Wang, P., 'China's accession to the WTO government procurement agreement challenges and the way forward'. Journal of International Economic Law, 12(3), pp. 663-706, 664, 2009. https://doi.org/10.1093/jiel/jgp029

[30] Meléndez-Ortiz, R., Monkelbaan, J. \& Riddell, G., 'China's global and domestic governance of climate change, trade and sustainable energy: exploring china's interests in a global massive scale-up of renewable energies', Working Paper, Indiana University Center for Chinese Politics and Business, pp. 1-73, 33, 24 March, 2012.

[31] Alexander Chipman Koty., 'Investing in china's green industries' China Briefing, 7 June, 2017. http://www.china-briefing.com/news/2017/06/07/chinas-climate-leadership -opportunities-foreign-investment.html

[32] Martin, G., 'Thin film technology on the international market' Advanced Science News 11 May, 2017. http://www.advancedsciencenews.com/thin-film-technologyinternational-market/ 
[33] Chinese Ministry of Commerce 'MOFCOM Department of Foreign Investment Administration Comments on China's Assimilation of Foreign Investment in JanuaryJuly 2017.' http://english.mofcom.gov.cn/article/newsrelease/policyreleasing/201708/ 20170802628440.shtml

[34] Cunningham, E.A., 'The state and the firm: china's energy governance in context' (Boston University Global Economic Governance Initiative Working Paper 1 March, 2015, p. 37). https://ash.harvard.edu/files/chinas-energy-working-paper.pdf 